\title{
CLONING AND EXPRESSION OF CELLULASE XF-818 OF Xylella fastidiosa IN Escherichia Coli
}

\author{
Nelson Arno Wulff ${ }^{1,2}$; Helaine Carrer ${ }^{3}$; Sérgio Florentino Pascholati1 * \\ ${ }^{\prime}$ USP/ESALQ - Depto. de Entomologia, Fitopatologia e Zoologia Agrícola, C.P. 9 - 13418-900 - Piracicaba, SP - \\ Brasil. \\ ${ }^{2}$ Fundecitrus, Av. Dr. Adhemar P. de Barros, 201 - 14801-970 - Araraquara, SP - Brasil. \\ ${ }^{3}$ USP/ESALQ - Depto. de Ciências Biológicas. \\ *Corresponding author <sfpascho@esalq.usp.br>
}

\begin{abstract}
Xylella fastidiosa's genome was the first of a plant pathogen to be completely sequenced. Through comparative sequence analysis many genes were identified and, among them, several potentially involved in plant-pathogen interaction. However, the biological role of each gene should be assigned experimentally. On this regard, heterologous protein expression is a powerful tool to produce proteins from such genes, allowing their characterization. X. fastidiosa lives inside xylem vessels and eventually would degrade pit membranes from xylem cells to move radialy into the host. The identification of several putative plant cell wall degrading enzymes on $X$. fastidiosa genome prompted the assession of the function of such proteins. The open reading frame (ORF) Xf-818 was cloned into expression vector pET20b and $E$. coli cells harboring such plasmid exhibited cellulase activity. Using IPTG at $0.4 \mathrm{mmol} \mathrm{L}^{-1}$ with a $12 \mathrm{~h}$ incubation at $32^{\circ} \mathrm{C}$ are the best conditions to produce higher amounts of heterologous protein. The enzyme degrades cellulose confirming the endoglucanase activity of Xf-818.
\end{abstract}

Key words: citrus variegated chlorosis, cellulases, cloning and expresssion

\section{CLONAGEM E EXPRESSÃO DA CELULASE XF-818 DE Xylella Fastidiosa EM Escherichia Coli}

\begin{abstract}
RESUMO: Xylella fastidiosa foi a primeira bactéria fitopatogênica que teve seu genoma completamente seqüenciado. A identificação de diversos genes, através de similaridade de sequiências, indicou os possíveis mecanismos de patogenicidade da bactéria. Entretanto, a determinação da função de um gene requer a confirmação experimental e, neste aspecto, a expressão heteróloga é uma poderosa ferramenta. $X$. fastidiosa coloniza somente o xilema das plantas hospedeiras e a identificação putativa de diversos genes semelhantes a enzimas que degradam a parede celular vegetal, estimularam o presente estudo de catacterização destas enzimas. A clonagem da ORF Xf-818 de X. fastidiosa no vetor de expressão pET20b possibilitou a produção da proteína heterologamente em E. coli. O emprego de IPTG a $0,4 \mathrm{mmol} \mathrm{L^{-1 }}$ com $12 \mathrm{~h} \mathrm{a} 32^{\circ} \mathrm{C}$, possibilitou as melhores condições para E. coli produzir a proteína heteróloga. Clones de E. coli que expressam Xf-818, apresentam atividade celulásica, degradando eficientemente a celulose. A identificação de Xf-818 como uma endoglicanase foi assim confirmada.

Palavras-chave: clorose variegada dos citros, celulases, clonagem e expressão
\end{abstract}

\section{INTRODUCTION}

Xylella fastidiosa Wells is a xylem restricted pathogen of several plants and important crops, causing different symptoms according to the host (Hopkins, 1989). Citrus variegated chlorosis (CVC) was first observed in the states of São Paulo and Minas Gerais (Brazil) in 1987 (Rossetti \& De Negri, 1990), and X. fastidiosa was identified as the etiological agent of CVC (Rossetti et al., 1990; Chang et al., 1993). The bacterium spreads among citrus trees by means of leafhopper sharpshooter vectors and infected budwoods (Rossetti et al., 1995; Lopes, 1996). CVC spread fast from 1987 to 1992 on citrus growing areas of the São Paulo State, and the main cause was the use of graft-infected seedlings with $X$. fastidiosa (Tubelis et al., 1993). In grapevines, this patogen causes the Pierce's Disease (PD), and most of the knowledge about the bacterium is derived from studies on this host.

$X$. fastidiosa is a major concern regarding losses on citrus plantations. The Fundecitrus estimates that in 2001 about $36 \%$ of the orange trees in São Paulo were infected, and that the highest incidence was in the most important region for citrus production, Bebedouro $\left(20^{\circ} 56^{\prime} 58^{\prime \prime} \mathrm{S}, 48^{\circ} 28^{\prime} 45^{\prime \prime} \mathrm{W}\right)$ and Barretos (20 33'26"S, $48^{\circ} 34^{\prime} 04^{\prime \prime W}$ ) (www.fundecitrus.com.br). Currently, producers deal with CVC through cultural practices.

A recent scientific advance was achieved by unravelling the genome of $X$. fastidiosa from citrus (Simpson et al., 2000). This genome has several poten- 
tially pathogenic or virulence associated factors and, among them, there is a streaking similarity with virulence mechanisms in Xanthomonas campestris (Simpson et al., 2000; Lambais et al., 2000; Dow \& Daniels, 2000). A search on candidate genes revealed an almost complete similar xantham gum operon (Silva et al., 2001), several putative plant cell wall degrading enzymes, regulatory components such as rpf gene family members (Dow \& Daniels, 2000), genes potentially involved in antibiotic, siderophores, and even toxin synthesis. Leite et al. (2002) described a potential mechanism driving adhesion to plant cells and aggregation, a hypothesis supported by several adhesion and pili genes putatively found in the $X$. fastidiosa genome (Simpson et al., 2000).

Among such diverse, but complementary, putative factors, the plant cell wall degrading enzymes deserve especial attention. The presence of a cellobiohydrolase, three endoglucanases, three xylanases, one polygalacturonase, one pectate lyase and the $\beta$-glucosidase and $\beta$ xylosidase (Table 1) provides the bacterium with a plantcell-degrading enzyme arsenal.

Hopkins (1985) did not detect cellulolytic and pectinolytic activity on culture medium of $X$. fastidiosa from grapevine. Fry et al. (1994) detected proteases produced by $X$. fastidiosa-PD but there was no correlation between enzyme production and virulence. Purcell \& Hopkins (1996) report that the movement of xylem limited bacteria between vessels would suggest the production of enzymes capable to degrade pit membranes. Adjacent middle layer and primary cell walls form the pit membrane, which are composed by pectic components such as pectin and pectate, cellulose and hemicelluloses. As cellulose and hemicellulose are structural components of primary walls, the degradation of such polymers would enable $X$. fastidiosa to move through pit membranes, moving from one cell to another, on radial spread into the host.

As cellulases and xylanases were found in the $X$. fastidiosa genome, this study worked on the hypothesis that these enzymes posses such hydrolytic activity. To test this hypothesis, a putative cellulase gene Xf-818 was cloned, introduced and expressed into E. coli to produce and purify the protein, allowing enzyme characterization.

E. coli expression system has several advantages: E. coli grows faster than $X$. fastidiosa and in a cheaper and simpler medium. Also, as E. coli does not have endoglucanase, all endoglucanase activity is derived from the cloned gene. As $X$. fastidiosa has three putative cellulases, expressing each one separately in E. coli make possible to circumvent co-elution of cellulases during purification steps. Cloned genes can also be engineered to produce proteins containing fusion tags designed to help in purification steps, such as hexahistidine tag, mal- tose binding protein and protein A (Nilsson et al., 1997). The optimization of the expression of the $X$. fastidiosa gene Xf-818 in E. coli, and the cellulase activity (EC 3.2.1.4 b-1,4 endoglucanase) of its protein product is herein described.

\section{MATERIAL AND METHODS}

Similarity searches between the translated open reading frame (ORF) sequence from Xf-818 and previously described proteins were made with Blast $p$ (Altschul et al., 1990) using the swissprot protein database at NCBI (http://www.ncbi.nlm.nih.gov/blast/Blast.cgi?). Prediction of localization of the signal peptide was achieved with SignalP V1.1 (Nielsen et al., 1997; http://www.cbs.dtu.dk/ services/SignalP/).

\section{Reagents and culture medium}

Oligonucleotides for both PCR and DNA sequencing were purchased from Operon and Life Technologies. Restriction enzymes and amplification reagents were from Gibco BRL. Sequencing reagents were purchased from Perkin Elmer. E. coli was grown on LB medium (Sambrock et al., 1989); solid medium contained agar at $1.8 \%(\mathrm{w} / \mathrm{v})$ and appropriate antibiotics were supplemented to this medium (50 $\mu \mathrm{g}$ kanamycin $\mathrm{mL}^{-1}$ and $100 \mu \mathrm{g}$ ampicillin $\mathrm{mL}^{-1}$ ).

\section{Plasmid, cosmid and $E$. coli strains}

Expression vector pET20b(+) (Novagen), Cosmid 07H04 containing ORF Xf-818 from $X$. fastidiosa $9 \mathrm{a} 5 \mathrm{c}$ employed during sequencing project (ONSA/FAPESP), the $E$. coli $\mathrm{DH} 5 \alpha$ cloning strain and strain BL21( $\lambda \mathrm{DE} 3)$ (Studier \& Moffatt, 1986; Novagen) were obtained from other institutes. Plasmids and cosmid were extracted through alkaline lysis (Sambrock et al., 1989) and were quantified on $0.8 \%$ agarose gels $(\mathrm{w} / \mathrm{v})$.

\section{Subcloning of Xf-818 into expression vector pET20b(+)}

The coding sequence of Xf-818 (Simpson et al., 2000) was amplified from cosmid 07H04 by PCR. Forward primer containing an engineered $N d e \mathrm{I}$ restriction site (underlined) at the beginning of the ORF (F592S1 5 ' CCGGTCGACATATGTCGTTTTCCAAACAC) and reverse primer containing a engineered HindIII restriction site spanning the stop codon (R592Hd 5'GGAAAAT AAGCTTCAATAGTTTGAAC) were employed. Around $50 \mathrm{ng}$ of cosmidial DNA, 0.2 pmoles of each primer, $20 \mathrm{mmol} \mathrm{L}^{-1}$ Tris- $\mathrm{HCl} \mathrm{pH} 8.4,50 \mathrm{mmol} \mathrm{L}^{-1}$ $\mathrm{KCl}, 1.5 \mathrm{mmol} \mathrm{L}^{-1}$ magnesium chloride, $200 \mu \mathrm{M}$ of each dNTP and $1.5 \mathrm{U}$ of Taq DNA polymerase were employed on PCR amplification in a $40 \mu \mathrm{L}$ volume. Amplification was preceeded by $3 \mathrm{~min}$ at $94^{\circ} \mathrm{C}$, followed by 35 cycles of $30 \mathrm{~s}$ at $94^{\circ} \mathrm{C}, 60 \mathrm{~s}$ at $60^{\circ} \mathrm{C}$, and $120 \mathrm{~s}$ at $72^{\circ} \mathrm{C}$. At the end of $35^{\text {th }}$ cycle, the reaction was kept for $10 \mathrm{~min}$ at $72^{\circ} \mathrm{C}$. 
PCR-amplified DNA was cut with NdeI and HindIII and linked to pET20b cut with the same enzymes. Electroporated E. coli DH5 $\alpha$ clones containing the plasmids were screened by restriction digestion. The coding region of $\mathrm{Xf}-818$ was sequenced to assure that no mutation was introduced during PCR amplification. The primers described above, primers $\mathrm{T} 7$ promoter (5'TAATACGACTCACTATAGGG) and T7 terminator (5'TGCTAGTTATTGCTCAGCGGT), and two internal primers that anneal inside Xf-818 (818intN - 5' GCGTCATCGGCTTGG and 818intC 5'CGCGCACGTGATTCC) were used. Sequence reads were analyzed on Phred + Phrap + Consed package (Gordon et al., 1998). Plasmid pNAW3, containing Xf-818 cloned into pET20b, was electroporated into competent E. coli BL21( $\lambda \mathrm{DE} 3)$.

\section{Expression of Xf-818 protein in E. coli}

Seven single colonies resulting from transformation of pNAW3 into BL21( $\lambda$ DE3) were selected and grown on liquid LB medium. After overnight growth $\left(37^{\circ} \mathrm{C}\right.$ at $\left.220 \mathrm{rpm}\right)$, an aliquot of $1 \mathrm{~mL}$ was centrifuged ( $1 \mathrm{~min} ; 10,000 \mathrm{~g}$ ), the pellet was suspended in the same medium and a $100 \mu \mathrm{L}$ aliquot was stored at $-20^{\circ} \mathrm{C}$ for electrophoresis. The remaining culture was induced with IPTG at $0.4 \mathrm{mmol} \mathrm{L}{ }^{-1}$. Cells were kept at $37^{\circ} \mathrm{C}, 200 \mathrm{rpm}$ for $3.5 \mathrm{~h}$. A drop of $50 \mu \mathrm{L}$ of each culture medium with cells of $E$. coli was deposited on the surface of a plate containing solid LB with carboxymethyl cellulose (CMC) at $0.1 \%(\mathrm{w} / \mathrm{v})$. Plates were stored overnight at $37^{\circ} \mathrm{C}$ and revealed for cellulase as described below. From the culture supernants, endoglucanase was evaluated through spectrophotometric assay and cell pellet was used to SDSPAGE.

Another assay was performed to determine the better temperature and time of harvesting after induction. An overnight culture of the single clone selected on the previous assay (electrophoresis, plate and spectrophotometric assay) was inoculated on $1.5 \mathrm{~L}$ of $\mathrm{LB}$ medium and grown for $3 \mathrm{~h}$ at $37^{\circ} \mathrm{C} / 220 \mathrm{rpm}$. The medium was induced with $0.4 \mathrm{mmol} \mathrm{L}^{-1} \mathrm{IPTG}$, divided into portions and stored at 28,31 or $37^{\circ} \mathrm{C}$ under agitation. One $\mathrm{mL}$ aliquots were withdrawn at $0,2,4,8$ and $19 \mathrm{~h}$ after induction. Each sample was centrifuged ( $2 \mathrm{~min}$; $12,000 \mathrm{~g}$ ) and the pellet was used on electrophoresis as described above. The supernatant was used to evaluate endoglucanase activity.

For time course endoglucanase activity, $300 \mathrm{~mL}$ of LB medium were inoculated with $5 \mathrm{~mL}$ of an overnight culture of BL21(DE3) harboring pNAW3 clone previously selected. The culture was grown for $3 \mathrm{~h}$, IPTG was added at $0.4 \mathrm{mmol} \mathrm{L}^{-1}$ final concentration and after $8 \mathrm{~h}\left(37^{\circ} \mathrm{C} / 280 \mathrm{rpm}\right)$ cells were pelleted by centrifugation $(10 \mathrm{~min} ; 5,000 \mathrm{~g})$. The pellet was suspended into buffer $\left(50 \mathrm{mmol} \mathrm{L}^{-1}\right.$ Tris-HCl pH 7.5, $300 \mathrm{mmol} \mathrm{L}^{-1} \mathrm{NaCl}$,
$10 \%$ glycerol and $\left.1 \mathrm{mmol} \mathrm{L}^{-1} \mathrm{PMSF}\right)$. Triton $\mathrm{X}-100$ was added to a final concentration of $0.1 \%$. After three cycles of freezing and thawing, $\mathrm{MgCl}_{2}\left(10 \mathrm{mmol} \mathrm{L}^{-1}\right)$ and DNaseI $\left(10 \mu \mathrm{g} \mathrm{mL}^{-1}\right)$ were added. All reagents were homogenized and standed at room temperature for $10 \mathrm{~min}$. This lysate was centrifuged to $5,000 \mathrm{~g}$ for $25 \mathrm{~min}$ at $4^{\circ} \mathrm{C}$. The resulting supernatant was centrifuged again at 40,000 $g$ for $30 \mathrm{~min}$ at $4^{\circ} \mathrm{C}$. We used ammonium sulfate at 20 and $80 \%$ saturation and EDTA was added to $1 \mathrm{mmol} \mathrm{L}^{-1}$ before protein precipitation. Each fraction was dialyzed against distilled water and the desalted solution was centrifuged $\left(20,000 \mathrm{~g} ; 10 \mathrm{~min} ; 4^{\circ} \mathrm{C}\right)$. Proteins pelleted at 80 $\%$ saturation were used on endoglucanase assays to confirm the cellulase activity of heterologous protein.

\section{SDS-PAGE and SDS-PAGE zymograms}

The same cell cultures employed on the plate test were used for electrophoresis to visualize the amount of recombinant protein. A $100-\mu \mathrm{L}$ aliquot of each culture, both before and after induction with $0.4 \mathrm{mmol} \mathrm{L}^{-1} \mathrm{IPTG}$, were centrifuged ( $2 \mathrm{~min} ; 12,000 \mathrm{~g}$ ) and the pellet was dissolved with $100 \mu \mathrm{L}$ buffer ( 1 volume of TE buffer and 1 volume of electrophoresis sample buffer). Lysozyme was added $\left(10 \mathrm{mg} \mu \mathrm{L}^{-1}\right)$ and kept for $15 \mathrm{~min}$ at $30^{\circ} \mathrm{C}$. This lysate was heated in a water bath at $100^{\circ} \mathrm{C}$ for $5 \mathrm{~min}$, cooled and centrifuged ( $2 \mathrm{~min} ; 12,000 \mathrm{~g}$ ). A $10-\mu \mathrm{L}$ aliquot of each sample was applied on the top of a $4.5 \%$ stacking gel. Resolving gel was at $10 \%$. SDS-PAGE was run according to Laemmli (1970). After electrophoresis run at $4^{\circ} \mathrm{C}$, the gel was stained with Coomassie blue.

To detect CMCase activity after SDS-PAGE, $0.1 \% \mathrm{CMC}$ was included in the polyacrylamide solution before gel was cast. After electrophoresis, the gel was washed and stored at $37^{\circ} \mathrm{C}$ into $20 \mathrm{mmol} \mathrm{L}$ Tris- $\mathrm{HCl}$ buffer, $\mathrm{pH}$ 7.2. After two buffer exchanges $(1.5 \mathrm{~h}$ each wash) the gel was immersed into the same buffer with $0.1 \%$ (v/v) Triton X-100. This buffer was exchanged twice and the gel was stored overnight at $37^{\circ} \mathrm{C}$ in buffer without Triton X-100. The gel was stained with Congo red and destained with $1 \mathrm{M} \mathrm{NaCl}$ washes (Park et al., 1998; Wood et al., 1988).

\section{Endoglucanase assay}

Plates with cultures had the cells washed off with water and killed with $2 \%$ sodium hipochloride. The medium was covered with Congo Red $0.1 \%$ (w/v) for $1 \mathrm{~h}$, washed with water and several times with $\mathrm{NaCl} 1 \mathrm{M}$. Cellulase positive clones give a yellow halo against a red background on this cellulase plate assay (Wood et al., 1988).

An indirect assay for endoglucanase was made by incubation of a $50-\mu \mathrm{L}$ aliquot of supernatant (from expression assay above) with $200 \mu \mathrm{L}$ of $1 \% \mathrm{CMC}(\mathrm{w} / \mathrm{v})$ into $50 \mathrm{mmol} \mathrm{L}^{-1}$ sodium acetate buffer, $\mathrm{pH} 5.2$. After $2 \mathrm{~h}$ at $40^{\circ} \mathrm{C}$, reducing sugars were determined according to the 
Lever procedure (Lever, 1972), having glucose as a standard. The amount of protein present in the supernatant was measured by the Bradford procedure (Bradford, 1976), having BSA as standard. One unit of endoglucanase (EC 3.2.1.4 cellulase, CMCase or $\beta$-1,4endoglucanase) is the amount of protein in milligrams enough to produce $1 \mu \mathrm{mol}$ of reducing sugars (an amount of $0.18 \mu \mathrm{g}$ of glucose as determined according to Lever, 1972) from the substrate by min (Foong \& Doi, 1992).

\section{RESULTS AND DISCUSSION}

On recent years, high-throughput genome analysis enabled several complete genomes to be unravelled. Although such information is invaluable, genomic data needs functional confirmation in order to allow biological roles of genes to be confirmed. Although a putative function can be assigned to an open reading frame (ORF) by sequence comparison, such information needs to be confirmed through analysis of the protein product of the putative gene. Also, characterization of the product is essential in case of enzymes to determine the specificity towards different substrates, stability and other properties (Hough \& Danson, 1999).

The coding sequence of 1779 bp from Xf-818 was sucessfully cloned into pET20b, creating pNAW3 (Figure 1). The Xf-818 gene is under the control of the inducible promoter $\mathrm{T} 7$, and remains translatable from its original start codon.

Simpson et al. (2000) have assigned putative functions to around $50 \%$ of ORFs from $X$. fastidiosa $9 \mathrm{a} 5 \mathrm{c}$, and among the genes described there are several potentially involved in plant-pathogen interaction, specially in plant cell wall degradation (Table 1). Using Blast (Altschul et al., 1990) we have analyzed the best matches of protein Xf-818 (Table 2) and the highest similarities were among bacterial endoglucanases. It has a better homology with EngXCA from Xanthomonas campestris pv. campestris, an endoglucanase with minor role on initial stages of pathogenic process in radish and turnip (Gough et al., 1988; 1990). All matches of endoglucanases Xf818 belong to the family 5 of glycoside hydrolases (Table 2) (Henrissat, 1991; Henrissat \& Bairoch, 1993). In fact, all three endoglucanases putatively found on $X$. fastidiosa (Xf-810, Xf-818 and Xf-2708) belong to family 5 (Simpson et al., 2000).

Protein Xf-818 has two domain structures, with a N-terminal domain composed of a catalytic domain of family 5 , interspersed by a lynker sequence to a type II cellulose binding domain (CBD) (Figure 2B). Cellulase activity was confirmed on CMC plates, a diagnostic test that shows the catalytic behavior of cellulases over cellulose chains (Figure 3). Congo red dye complexes with cellulose polymer but not with oligomers formed after its cleavage. Therefore, alterations associated with dye bind- ing can be used to monitor hydrolytic activity on endoglucanases, but not cellobiohydrolases, another kind of cellulases acting over cellulose (Wood et al., 1988). Cellulase activity was also assessed by the formation of reducing sugars during hydrolysis of CMC (Figure 4). Confirmation of Xf-818 protein as a endoglucanase, sup-

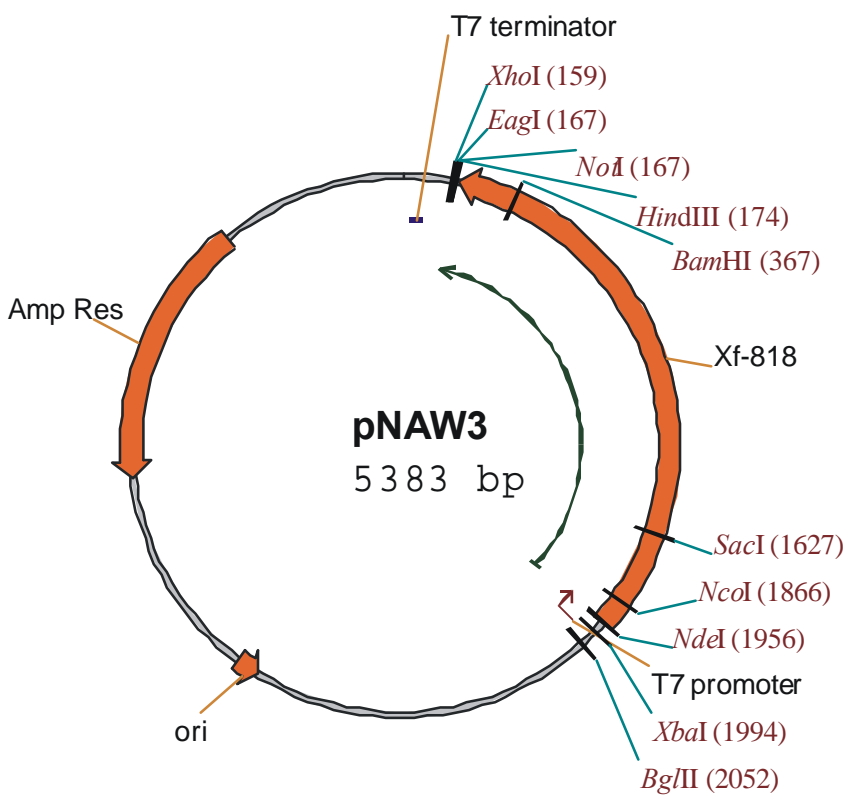

Figure 1 - Restriction map of the plasmid pNAW3. Gene Xf-818 was cloned between $\mathrm{NdeI}$ and HindIII sites, under control of the $\mathrm{T} 7$ promoter. It has $\mathrm{T} 7$ terminator at its end, after the HindIII site. Important features of the plasmid are shown.

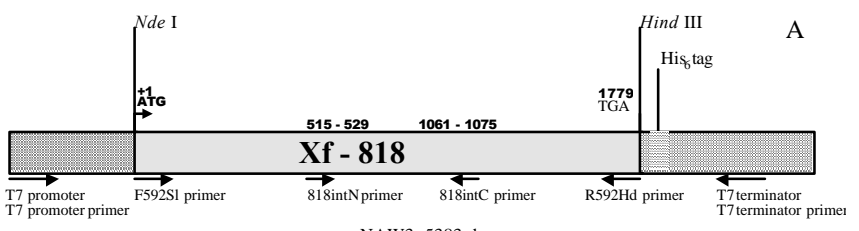

pNAW3 5383 bp

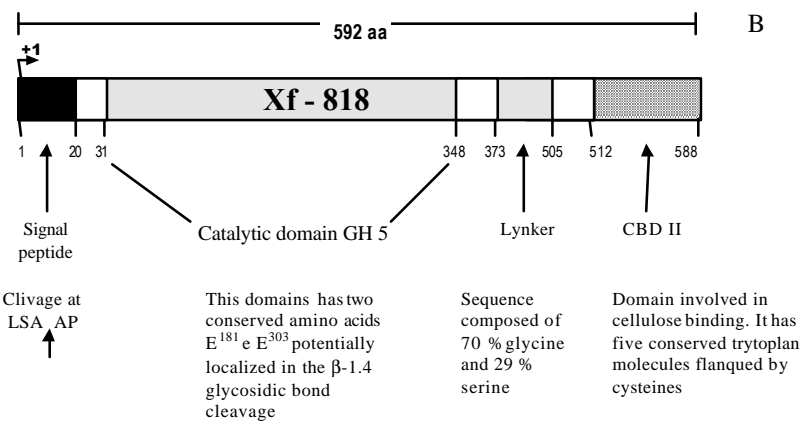

Figure 2 - (A) Annealing positions of primers on the Xf-818 gene cloned into pNAW3. NdeI and HindIII sites are shown as well as flanking structures of the pET20b plasmid; (B) Structure of Xf-818 protein (NCBI AAF83628/ SwissProt Q9PF60), as determined from the sequence derived from ORF identified on $X$. fastidiosa $9 \mathrm{a} 5 \mathrm{c}$ (Simpson et al., 2000). Relevant features of Xf-818 protein domains are shown, with numbered positions referring to beginning and end of domains or specific structures. 
Table 1 - Putative genes of Xylella fastidiosa related to plant cell wall degrading enzymes (PCWDE).

\begin{tabular}{|c|c|c|c|c|c|}
\hline Gene $^{1}$ & Putative function $^{2}$ & Size $(b p)^{*}$ & Protein $(\mathrm{aa})^{*}$ & $\mathrm{kDa}^{*}$ & e-value* \\
\hline Xf-1267 & Cellobiohydrolase & 2052 & 683 & 70.9 & $\mathrm{e}^{-142}$ \\
\hline Xf-810 & Endoglucanase & 1698 & 565 & 61.6 & $3 e^{-50}$ \\
\hline Xf-818 & Endoglucanase & 1779 & 592 & 60 & $1 \mathrm{e}^{-145}$ \\
\hline Xf-2708 & Endoglucanase & 1071 & 356 & 39.3 & $2 e^{-85}$ \\
\hline$X f-878$ & Endoxylanase & 774 & 257 & 28.6 & $9 \mathrm{e}^{-04}$ \\
\hline Xf-2395 & Acetylxylan esterase & 861 & 286 & 32.2 & $1 \mathrm{e}^{-13}$ \\
\hline Xf-2779 & Endoxylanase & 2712 & 903 & 101.1 & $8 e^{-15}$ \\
\hline Xf-2466 & Polygalacturonase & 1636 & 544 & 59.8 & $\mathrm{e}^{-112}$ \\
\hline Xf-2359 & Pectate lyase & 711 & 236 & 26.1 & $1 \mathrm{e}^{-10}$ \\
\hline Xf-439 & $\beta$-glucosidase & 2304 & 767 & 83.2 & $\mathrm{e}^{-137}$ \\
\hline Xf- 845 & $\beta$-xylosidase & 2649 & 882 & 95.0 & $2 e^{-80}$ \\
\hline
\end{tabular}

*bp=base pairs, aa=amino acids, $\mathrm{kDa}=$ kilodalton, e-value $=$ expect value

${ }^{1}$ Gene number, size in bp and amino acid number are from Simpson et al. (2000) found at http://aeg.lbi.ic.unicamp.br/xf/.

${ }^{2}$ Gene function was assigned according to the similarity found with other genes deposited at GenBank and the highest similarity is shown on the last column.

Table 2 - Homologs of Xf-818 protein as found on protein-protein Blast search at NCBI (http://www.ncbi.nlm.nih.gov/ BLAST/ $/)^{1}$.

\begin{tabular}{|c|c|c|c|c|}
\hline Acession Number & Cellulase & Organism & Probability & Score \\
\hline P19487 & Endo-1,4- $\beta$-glucanase [engXCA] & X.c.pv. campestris & $\mathrm{e}^{-137}$ & 487 \\
\hline P23548 & Endo-1,4- $\beta$-glucanase & Bacillus polymyxa & $4 e^{-77}$ & 287 \\
\hline P54583 & Endo-1,4- $\beta$-glucanase E1 & Acidothermus cellulolyticus & $4 e^{-64}$ & 244 \\
\hline P10474 & $\begin{array}{l}\text { Endo-1,4- } \beta \text {-glucanase / 1,4 - } \beta \text { - } \\
\text { cellobiohydrolase }\end{array}$ & $\begin{array}{l}\text { Caldicellulosiruptor } \\
\text { saccharolyticus }\end{array}$ & $2 \mathrm{e}^{-42}$ & 172 \\
\hline Q05332 & Endo- 1,4 - $\beta$-glucanase $\mathrm{G}$ & Clostridium thermocellum & $1 \mathrm{e}^{-41}$ & 169 \\
\hline P50400 & Endo-1,4- $\beta$-glucanase D & Celullomonas fimi & $5 e^{-33}$ & 140 \\
\hline P04956 & Endo-1,4- $\beta$-glucanase B & Clostridium thermocellum & $1 e^{-30}$ & 133 \\
\hline P27033 & Endo-1,4- $\beta$-glucanase $C$ & Pseudomonas fluorescens & $3 e^{-18}$ & 92 \\
\hline
\end{tabular}

port annotation that was performed during a sequencing project (Simpson et al., 2000), a fact that elicits assuming that other putative plant cell wall degrading enzymes are in fact true enzymes that can act over the plant cell wall (Table 1).

To optimize protein production, an E. coli clone that produces high amount of heterologous protein was selected, and a few parameters that can influence protein production and accumulation were evaluated. The clone of $E$. coli harboring pNAW3 and named clone $\mathrm{b}$ is the best Xf-818 protein producer to be employed when scaling up the process of heterologous protein expression (Table 3). Such analysis was confirmed by means of electrophoretic analysis of total protein (Figure 5A).

The next step was to analyze the accumulation of cellulase in the selected clone of $E$. coli after induction. Protein accumulation increased positively a few hours from induction, reaching the highest rate $19 \mathrm{~h}$ after induction (Figure 5B). The rate of protein accumulation was apparently dependent of temperature during ex-
Table 3 - Cellulase activity of selected clones of E. coli BL21(DE3) harboring pNAW3 after $0.4 \mathrm{mmol} \mathrm{L}^{1}$ IPTG induction.

\begin{tabular}{lccc}
\hline Clone $^{1}$ & $\mu$ g glucose produced & SA $^{3}$ & Plate assay $^{4}$ \\
\hline pNAW3 a & $3.41 \pm 0.56$ & 2.65 & Positive \\
pNAW3 b** & $7.02 \pm 1.48$ & 5.52 & Positive \\
pNAW3 c & $1.67 \pm 0.27$ & 1.41 & Positive \\
pNAW3 d & $3.64 \pm 0.17$ & 2.94 & Positive \\
pNAW3 e & $3.96 \pm 0.94$ & 3.26 & Positive \\
pNAW3 f & $3.95 \pm 1.2$ & 3.30 & Positive \\
pNAW3 g & $1.55 \pm 0.53$ & 1.14 & Positive \\
pET20 b & $-1.43 \pm 0.64$ & nd & Negative
\end{tabular}

${ }^{1}$ Double asterisk indicates selected clone for cellulase production; ${ }^{2}$ Mean of 3 samples \pm standard deviation;

${ }^{3} \mathrm{SA}=$ Specific activity ( $\mu \mathrm{g}$ glucose per $\mathrm{mg}$ of protein on sample per $\min )$; nd = not determined;

${ }^{4}$ Carboxymethyl cellulose degradation on plate assay (LB medium with $0.1 \% \mathrm{CMC})$. Fifty $\mu \mathrm{L}$ of an induced culture was grown overnight, medium was stained with Congo red and destained with $\mathrm{NaCl} 1 \mathrm{M}$. 


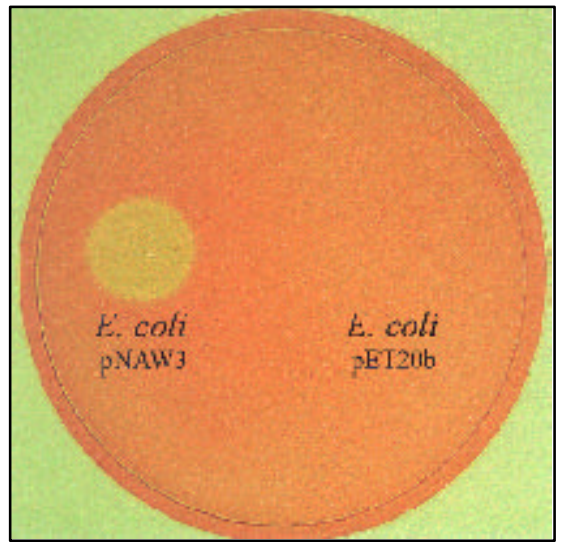

Figure 3 - Cellulase plate assay showing cellulose degradation by the action of Xf-818 expressed in E. coli BL21(DE3) by pNAW3. Untransformed E. coli was taken as control. Yellow-white halos indicate cellulose degradation.

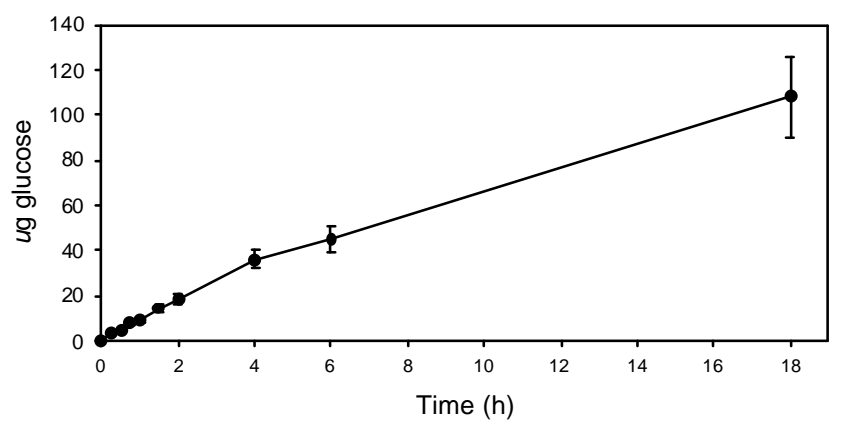

Figure 4 - Reducing sugars produced by Xf- 818 during hydrolysis of $\mathrm{CMC}$ at $40^{\circ} \mathrm{C}$. Measurements of reducing sugars were performed at indicated time intervals. Mean of 3 replicates \pm standard deviation.

pression. At $37^{\circ} \mathrm{C}$ protein accumulated faster, but it reached a slightly higher level at the lower temperature. A suitable option is to keep the culture medium at $32^{\circ} \mathrm{C}$ after IPTG induction and then perform protein extraction after $12 \mathrm{~h}$.

Confirmation that Xf-818 has cellulase activity, considered as an endoglucanase by the Congo red assay is by far the most important fact. Endoglucanase Xf- 818 produces increasing amounts of reducing sugars in relation to incubation time (Figure 4), an indication of high activity and stability. An interesting feature of many carbohydrate hydrolysing enzymes is the ability to bind to the substrate, a characteristic also found for cellulases, that is mediated by a domain called cellulose binding domain, which is independent of the catalytic domain (Figure 2B). Although Hopkins (1985) did not detected cellulase activity on the culture medium of $X$. fastidiosa PD, Scarpari (2001) was able to detect the presence of mRNA of Xf-818 on the culture medium, an indicator of cellulase production by $X$. fastidiosa $9 \mathrm{a} 5 \mathrm{c}$.

The ability to knockout $X$. fastidiosa genes (Monteiro et al., 2001; Silva Neto et al., 2002) opens the way to analyze functionally $X$. fastidiosa genes, such as
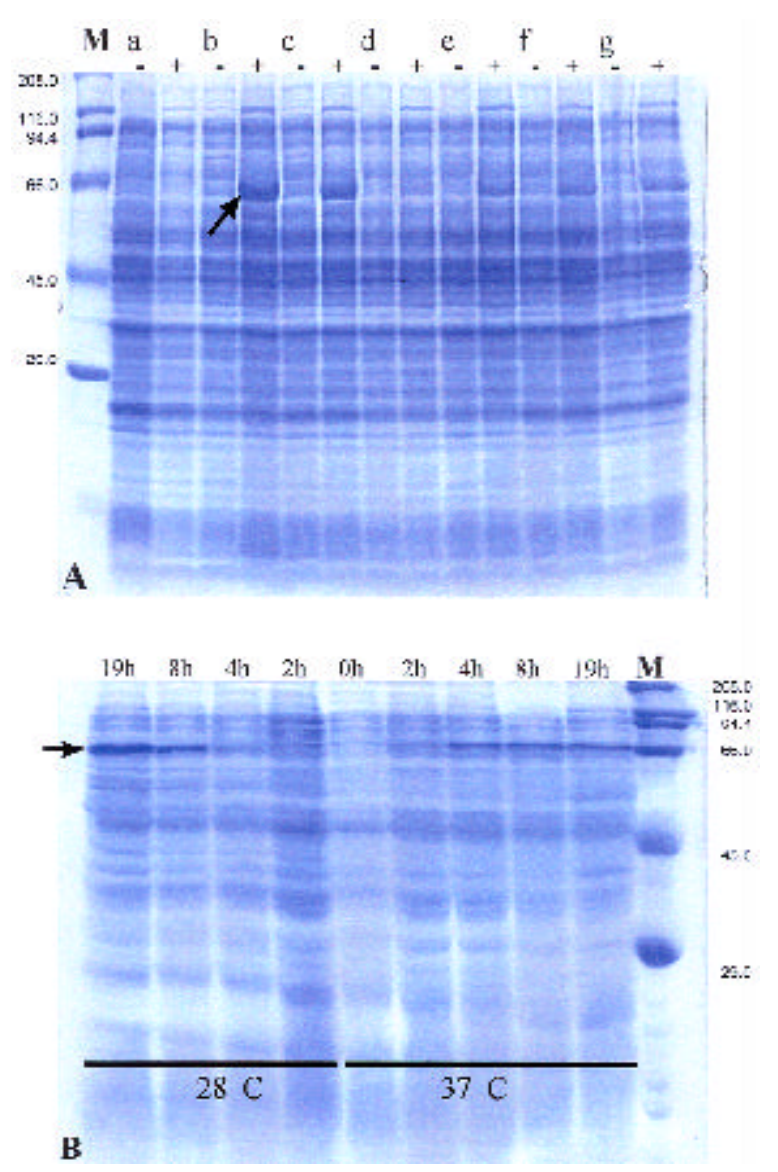

Figure 5 - SDS-PAGE of BL21(DE3) clones expressing gene Xf-818 (pNAW3) on gel at $10 \%$. A) Letters refer to single pNAW3 clones: $(-)$ and $(+)$ are clones either without or with IPTG induction, respectively. B) Culture aliquots were taken at indicated times after IPTG induction and electrophoresed. $\mathrm{M}=$ high molecular weight protein markers $(\mathrm{kDa})$.

Xf-818 and addresses the role of this protein during plantpathogen interaction. Cellulases have minor roles on the beginning of symptom development as assessed by cellulase mutants of E. carotovora subsp. carotovora (Mäe et al., 1995), Ralstonia solanacearum (Roberts et al., 1988) and X. c. pv. campestris (Gough et al., 1990). However, this pattern is different with Clavibacter michiganensis ssp. michiganensis (Jahr et al., 2000) and C. m. ssp. sepedonicus (Laine et al., 2000), since endoglucanases are essential for symptom development.

The next step is to produce and purify high amounts of Xf- 818 to characterize its substrate specificity, raise antibodies and evaluate its expression during citrus colonization by $X$. fastidiosa. The recent sequencing of other $X$. fastiosa strains, such as Dixon strain from almond, Ann1 from oleander (Bhattacharyya et al., 2002) and a grapevine strain (Van-Sluys et al., 2003), opens the possibility to study the diversity of pathogenicity factor among strains of the same bacterium, but with different host range. 


\section{ACKNOWLEDGMENTS}

This work was supported by grant from FAPESP (Fundação de Amparo à Pesquisa do Estado de São Paulo). First author was supported by a scholarship from FAPESP, and the third author was fellow of $\mathrm{CNPq}$ (Conselho Nacional de Desenvolvimento Científico e Tecnológico). Authors also thank Dra. M. Fiore (USP/CENA), Dr. J. Ferro (UNESP/Jaboticabal) and Dra. M.L. Targon (IAC/ CCSM) for providing essential material for this research.

\section{REFERENCES}

ALTSCHUL, S.F.; GISH, W.; MILLER, W.; MYERS, E.W.; LIPMAN, D.J. Basic local alignment search tool. Journal of Molecular Biology, v.215, p.403-410, 1990.

BHATTACHARYYA, A.; STILWAGEN, S.; IVANOVA, N. et al., Wholegenome comparative analysis of three phytopathogenic Xylella fastidiosa strains. Proceeding of the National Academy of Sciences of USA, v.99, p.12403-12408, 2002.

BRADFORD, M.M. A rapid and sensitive method for the quantitation of microgram quantities of protein utilizing the principles of protein-dye binding. Analytical Biochemistry, v.72, p.248-254, 1976.

CHANG, C.J.; GARNIER, M.; ZREIK, L.; ROSSETTI, V.; BOVÉ, J.M. Culture and serological detection of the xylem-limited bacterium causing citrus variegated chlorosis and its identification as a strain of Xylella fastidiosa. Current Microbiology,v.27, p.137-142, 1993

DOW, J.M.; DANIELS, M.J. Xylella fastidiosa genomics and bacterial pathogenicity to plants. Yeast, v.17,p.263-271, 2000.

FOONG, F.C.-F.; DOI, R.H. Characterization and comparison of Clostridium cellulovorans endoglucanases-xylanases EngB and EngD hyperexpressed in Escherichia coli. Journal of Bacteriology, v.174, p.1403-1409, 1992.

FRY, S.M.; HUANG, J.S.; MILHOLLAND, R.D. Isolation and preliminary characterization of extracellular proteases produced by strains of Xylella fastidiosa from grapevines. Phytopathology, v.84, p.357-363, 1994.

GORDON, D.; ABAJIAN, C.; GREEEN, P. Consed: a graphical tool for sequence finishing. Genome Research , v.8, p. 195-202, 1998.

GOUGH, C.L.; DOW, J.M.; BARBER, C.E.; DANIELS, M.J. Cloning of two endoglucanases genes of Xanthomonas campestris pv. campestris: analysis of the role of the major endoglucanase in pathogenicity. Molecular Plant Microbe Interactions, v.1, p.275-281, 1988.

GOUGH, C.L.; DOW, J.M.; KEEN, J.; HENRISSAT, B.; DANIELS, M.J. Nucleotide sequence of the engXCA gene encoding the major endoglucanase of Xanthomonas campestris pv.campestris. Gene, v.89, p.53-59, 1990

HENRISSAT, B. A classification of glycosyl hydrolases based on aminoacid sequence similarities.Biochemical Journal, v.280, p.309-316, 1991.

HENRISSAT, B.; BAIROCH, A. New families in the classification of glycosyl hydrolases based on amino-acid sequence similarities. Biochemical Journal, v.293, p.781-788, 1993.

HOPKINS, D.L. Physiological and pathological characteristics of virulent an avirulent strains of the bacterium that causes Pierce's disease of grapevine. Phytopathology, v.75, p.713-717, 1985.

HOPKINS, D.L. Xylella fastidiosa: xylem-limited bacterial pathogen of plants. Annual Review of Phytopathology, v.27, p.271-290, 1989.

HOUGH, D.W.; DANSON, M.J. Extremozymes. Current Opinion i n Chemical Biology, v.3, p.39-46, 1999.

JAHR, H.; DREIER, J.; MELETZUS, D.; BAHRO, R.; EICHENLAUB, R. The endo- $\beta$-1,4-glucanase CelA of Clavibacter michiganensis subsp. michiganensis is a pathogenicity determinant required for induction of bacterial wilt of tomato. Molecular Plant Microbe Interactions, v.13, p.703-714, 2000 .

LAEMMLI, U.K. Cleavage of structural proteins during the assembly of the head of bacteriophage T4. Nature, v.227, p.680-685, 1970.

LAINE, M.J.; HAAPALAINEN, M.; WAHLROSS, T.; KANKARE, K.; NISSINEN, R.; KASSUWI, S.; METZLER, M.C. The cellulase encoded by the native plasmid of Clavibacter michiganensis ssp. sepedonicus plays a role in virulence and contains an expansin-like domain. Physiological and Molecular Plant Pathology, v.57, p.221-233, 2000.
LAMBAIS, M.R.; GOLDMAN, M.H.S.; CAMARGO, L.E.A.; GOLDMAN, G.H. A genomic approach to the understanding of Xylella fastidiosa pathogenicity. Current Opinion in Microbiology, v.3, p.459-462, 2000.

LEITE, B.; ISHIDA, M.L.; ALVES, E.; CARRER, H.; PASCHOLATI, S.F.; KIT AJIMA,E.W. Genomics and X-ray microanalysis indicates that $\mathrm{Ca}^{2+}$ and thiols mediate the aggregation and adhesion of $X$. fastidios $a$. Brazilian Journal of Medical and Biological Research, v.35, p.645-650, 2002.

LEVER, M. A new reaction for colorimetric determination of carbohydrates. Analytical Biochemistry, v.47, p.273-279, 1972.

LOPES, J.R.S. Estudos com vetores de Xylella fastidiosa e implicações no manejo da clorose variegada dos citros. Laranja, v.20, p.329-344, 1996.

MÄE, A.; HEIKINHEIMO, R.; PALVA, E.T. Structure and regulation of Erwinia carotovora subsp. carotovora SCC 3193 Cellulase gene celV1 and the role of cellulase in phytopathogenicity. Molecular and General Genetics, v.247, p.17-26, 1995.

MONTEIRO, P.B.; TEIXEIRA, D.C.; P ALMA, R.R.; GARNIER, M.; BOVE, J.M.; RENAUDIN, J. Stable transformation of the Xylella fastidiosa citrus variegated chlorosis strain with oriC plasmids. Applied and Environmental Microbiology, v.67, p.2263-2269, 2001.

NIELSEN, H.; ENGELBRECHT, J.; BRUNAK, S.; VON HEIJNE, G. Identification of prokaryotic and eukaryotic signal peptides and prediction of their cleavage sites. Protein Engineering, v.10, p.1-6, 1997.

NILSSON, J.; ST AHL, S.; LUNDEBERG, J.; UHLÉN, M.; NYGREN, P.A. Affinity fusion strategies for detection, purification, and immobilization of recombinant proteins. Protein Expression and Purification, v.11, p.1-16, 1997

PARK, Y.W.; LIM, S.T.; YUN, H.D. Cloning and sequencing of the celA gene encoding CMCase of Erwinia carotovora subsp.carotovora LY34. Molecules and Cells, v.8, p.27-35, 1998.

PURCELL, A.H.; HOPKINS, D.L. Fastidious xylem-limited bacterial plant pathogens. Annual Review of Phytopathology, v.34,p.131-151, 1996.

ROBERTS, D.P.; DENNY, T.P.; SCHELL, M.A. Cloning of the egl gene of Pseudomonas solanacearum and analysis of its role in phytopathogenicity. Journal of Bacteriology, v.170, p.1445-1451, 1988.

ROSSETTI, V.; DE NEGRI. D. Clorose variegada dos citros: revisão. Laranja, v.11, p.1-14, 1990.

ROSSETTI, V; GARNIER, M.; BOVÉ, J.M.; BERETTA, M.J.G.; TEIXEIRA, A.R.R.; QUAGGIO, J.A.; DE NEGRI, J.D. Présence de bactéries dans le xylème d'oranges atteints de chlorose variégée, une nouvelle maladie des agrumes au Brésil. Comptus Rendus de Academie Sciences Paris, v.310, p.345-349, 1990.

ROSSETTI, V.; CARVALHO, M.L.V.; CHAGAS, C.M. Ensaios de transmissão de clorose variegada dos citros (CVC) em campo. Fitopatologia Brasileira, v.20, p.67, 1995. Suplemento.

SAMBROCK, J.; FRITISCH, E.F; MANIATIS, J. Molecular cloning .2.ed. Plainview: Cold Spring Harbor Laboratory. Press, 1989.

SCARPARI, L.M. Modulação da expressão de genes de patogenicidade putativos em Xylella fastidiosa sob condições de baixa e alta densidade celular. Piracicaba: USP/ESALQ, 2001. 85p. (Dissertação - Mestrado)

SILVA, F.R.DA; VETORE, A.L.; EDSON, L.K.; LEITE, A.; ARRUDA, P. Fastidian gum: the Xylella fastidiosa exopolysaccharide possibly involved in bacterial pathogenicity. FEMS Microbiology Letters, v.203, p.165-171, 2001.

SILVA NET O, J.F.; KOIDE, T.; GOMES, S.L.; MARQUES, M.V. Sitedirected gene disruption in Xylella fastidiosa. FEMS Microbiology Letters, v.210, p.105-110, 2002.

SIMPSON, A.J.G.; REINACH, F.C.; ARRUDA, P. et al. The genome sequence of the plant pathogen Xylella fastidiosa . Nature, v.406, p.151-159, 2000.

STUDIER, F.W.; MOFFAT T, B.A. Use of bacteriophage-T7 RNApolymerase to direct selective high-level expression of cloned genes. Journal of Molecular Biology, v.189, p.113-130, 1986.

TUBELIS, A.; BARROS, J.C.; LEITE, R.M.V.B. Difusão da clorose variegada dos citros em pomares comerciais de laranja doce no Brasil. Laranja, v.14, p.239-254, 1993.

VAN-SLUYS, M.A.; OLIVEIRA, M.C.; MONTEIRO-VITORELLO, C.B. et al., Comparative analyses of the complete genome sequences of Pierce's disease and citrus variegated chlorosis strains of Xylella fastidiosa . Journal of Bacteriology, v.185, p. 1018-1026, 2003.

WOOD, P.J.; ERFLE, J.D.; TEATHER, R.M. Use of complex formation between congo red and polysaccharide in detection and assay of polysaccharide hydrolases. Methods in Enzymology, 160, p.59-74, 1988.

Received October 01, 2002

Accepted August 19, 2003 